\title{
隆起性皮膚線維肉腫
}

妊娠を契機に急速に増大した隆起性皮膚線維肉腫 の 1 例

\section{Accelerated growth of dermatofibrosarcoma protuberans induced by pregnancy}

Kyoko TAMADA *, Tatsuhiko MORIOKA *, Yasuo NAKAMURA*

* Department of Dermatology, Yamada Red Cross Hospital

Dermatofibrosarcoma protuberans (DFSP) are uncommon skin tumors that have a high incidence of local recurrence even with wide surgical margin, but DFSP rarely metastasize. We report a case of DFSP that showed accelerated growth during pregnancy.

Immunohistochemical stains for CD34, S-100 protein, factor XIIIa, and estrogen and progesterone receptors were performed on biopsy specimens. Previous reports showed expression of progesterone and PDGF receptor which may be factors that accounts for their accelerated growth during pregnancy. [Skin Cancer (Japan) 2002 ; $17: 51-53]$

Key words : DFSP, Pregnancy, Progesterone, PDGF

はじめに

隆起性皮膚線維肉腫 (以下DFSP) は一般に緩 徐な発育を示し，遠隔転移が稀であることか ら, intermediate malignancy の線維性腫瘍と考 えられている。今回我々は妊娠を契機に急速に 増大したDFSPの 1 例を経験した。妊娠に伴う 生化学的変化が本腫瘍の増大に影響を及ぼす可 能性に着目し, 若干の文献的考察とともに自験 例を報告する。

\footnotetext{
* 山田赤十字病院皮虐科
}

症例

$$
\begin{aligned}
& \text { 患 者: } 20 \text { 歳, 女性 } \\
& \text { 初 診: } 2000 \text { 年 } 3 \text { 月 } 16 \text { 日 } \\
& \text { 主 訴:下腹部の皮下腫瘤 }
\end{aligned}
$$

家族歴，既往歴：特記すべきことなし。

現病歴：10歳頃より下腹部左側に無痛性皮 下硬結が出現するも放置していたが，今回妊娠 を契機に増大してきたため, 妊娠 3 力月時に当 科を受診。

現 症: 下腹部左側に, $50 \times 50 \mathrm{~mm}$ の弾性硬 の皮下硬結を認め, 表面の一部に拇指頭大の紅 色皮膚結節を伴っていた (図 1)。腫瘤は下床と 


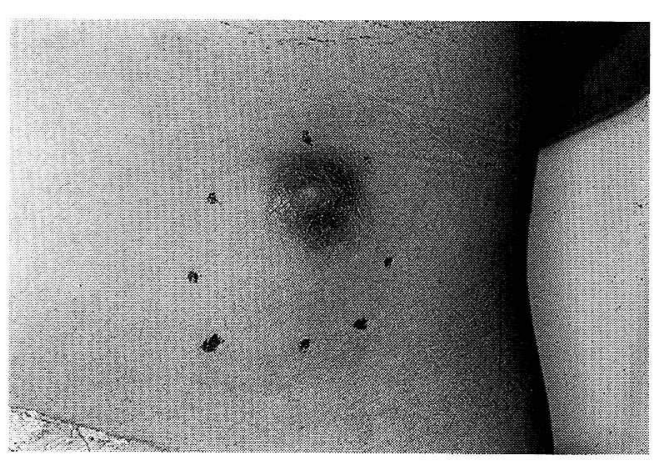

図 1. 妊娠 3 力月時の臨床像

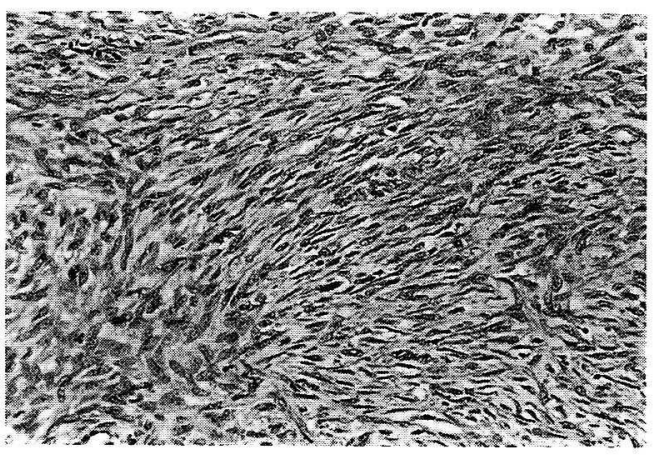

図 3.病理組織像（H.E. 染色，強拡大）

腫瘍細胞の核異型は顕著ではなく, 分裂像,

巨細胞もほとんどみられない

の可動性は比較的良好であった。

臨床検查所見 : 白血球, CRP の上昇と軽度の 貧血，アルブミンの低下以外，異常はみられな かった。所属リンパ節は触知しなかった。

病理組織学的所見：真皮上層から皮下組織 に，紡錘形あるいは楕円形の核を有する線維芽 細胞様の腫瘍細胞が密に増殖し, 一部では軽度 の storiform patternがみられた（図 2 )。腫瘍 細胞は, 核の大小不同は顕著ではなく, 分裂像 もわずかで，巨細胞はみられなかった（図 3)。

免疫組織染色：CD34, ビメンチンが陽性, XIIIa 因子，s-100 蛋白は陰性であった。エスト ロゲンレセプター, プロゲステロンレセプター 染色はともに陰性であった。

治療および経過：病理および免疫組織所見よ

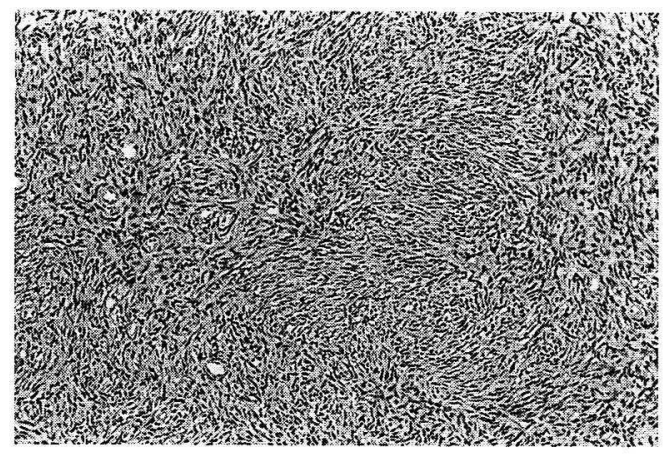

図 2.病理組織像（H.E. 染色，弱拡大） 線維芽細胞様細胞の密な増殖と, 一部で軽度 の storiform pattern がみられた

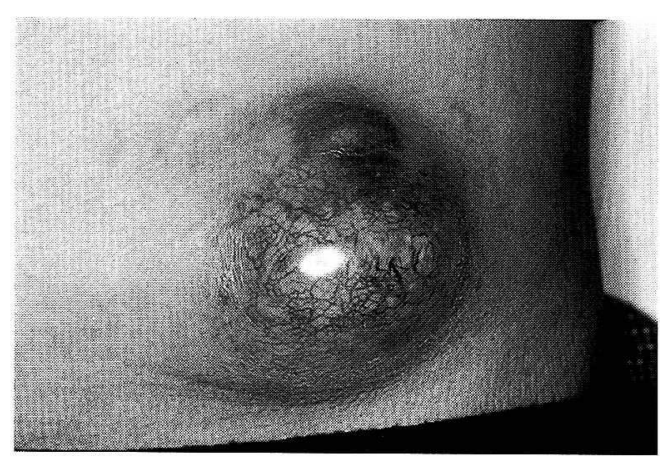

図 4. 妊娠 6 力月時の臨床像

り DFSP と診断し, 出産後に切除予定としたが, 妊娠 6 力月時に腫瘍は $80 \times 70 \mathrm{~mm}$ と急速な増大 をみた（図 4 ）。患者，家族の希望もあり，硬膜 外麻酔下で腫瘍を辺縁より $3 \mathrm{~cm}$ 離し, 筋膜を含 めて切除後, 分層植皮術を施行した。術後の経 過は良好で, 満期で正常女児を出産した。その 後，現在まで局所再発，転移は認めていない。

\section{考察}

従来より血管拡張性肉芽腫, 悪性黒色腫など は妊娠中に増大寸る皮膚腫瘍として知られてい

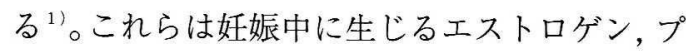
ロゲステロン， $\mathrm{MFH}$ などのホルモン量の変動 が関与すると考えられているが21，妊娠を機に 
増大した DFSP の報告は本邦ではみられず，海 外で少数報告されているのみである。DFSP の 増大と妊娠との関係は未だ明らかではないが, parlette ら ${ }^{3)}$ は， 妊娠中に増加する plateletderived-growth factor (以下 PDGF) とプロゲス テロンの両者の関与を指摘している。growth factor の一種である PDGF は, 血清中に存在す る血管平滑筋細胞の増殖因子として発見され， 血管内皮細胞，線維芽細胞，マクロファージな ど多くの細胞で産生, 分泌されている。機能的 には，線維芽細胞に対する強い増殖刺激能と遊 走促進作用を持つ。さらにTaniuchi ら ${ }^{4)}$ は DFSP の腫瘍細胞に PDGF レセプターの発現を 証明し, PDGF の増加が DFSP の増大に直接関 与する可能性を示した。

一方，プロゲステロンは妊娠成立後は胎盤か ら分泌され, 妊娠維持, 体温上昇, 乳腺発育作 用を示し，妊娠の経過とともに増加する。DFSP における免疫染色では，エストロゲンレセプ ターが全例陰性であるのに対し，プロゲステロ ンレセプターは妊婦，非妊婦，男性例のいずれ もが陽性となり ${ }^{3)}$, その重要性が示唆される。妊 娠に伴うプロゲステロンの増加は， PDGFに よってさらに促進され，DFSPの細胞増殖を促 すものと思われる。

治療に関して,一般にDFSPの転移能は低く, 妊婦例で母体および胎児への転移例は報告され
ていないことから ${ }^{5)}$, 妊娠中絶の必要はないと される ${ }^{6)}$ 。治療の時期については, 妊娠中の手術 に伴うリスクを考慮すべきであるが，外科的切 除を安易に先延ばしすべきではないという考 え 3)6)もみられる。妊娠を契機に増大した DFSP の報告例は少なく，両者の因果関係や治 療時期の問題も含め, 今後さらなる症例の蓄積 が必要と考えられる。

\section{文献}

1） Takako, T.：妊娠に伴う皮膚の変化（綜説）。 Derma. 36:1-6, 2000.

2) Kawakami, M.:pyogenic granuloma. 皮膚病診療, $16: 522-524,1994$.

3) Parlette, E., Kathleen, J.S., Marguerite, G. : Accelerated growth of dermatofibrosarcoma protuberans during pregnancy. J. Am. Acad. Dermatol., Nov : 778-783, 1999.

4) Taniuchi, K., Yamada, Y., Nonomura, A. : Immunohistoochemical analysis of plateletderived growth factor and its receptors in fibrohistiocytic tumors. J. Cutan Pathol., 24 : 393397, 1997.

5) Rademaker, B., Angelillo, M., Reiman, H. : Dermatofibrosarcoma protuberans:a review of 73 cases. Eur. J. Plast. Surg., 13 : 251-255, 1990.

6) Har-Shai, Y., Govrin-Yehudain, J., Ullmann, Y. : Dermatofibrosarcoma Protuberans Appearing During Pregnancy. Annals of Plastic Surgery, 1: 91-93, 1993. 